\title{
Longterm Biosafety Assessment of A Genetically Modified (GM) Plant: The Genetically Modified (GM) Insect-Resistant Bt11 Corn Does Not Affect the Performance of Multi-Generations or Life Span of Mice
}

\author{
Yoshihiko Haryu ${ }^{1}$, Yoko Taguchi ${ }^{1}$, Eisui Itakura ${ }^{1}$, Osamu Mikami ${ }^{2}$, Katsuhiro Miura ${ }^{2}$, \\ Takakiyo Saeki ${ }^{2}$ and Yasuyuki Nakajima,* \\ ${ }^{1}$ Animal Care, National Institute of Animal Health, Kannondai, Tsukuba 305-0856, Japan \\ ${ }^{2}$ Team for Safety Research, National Institute of Animal Health, Kannondai, Tsukuba 305-0856, Japan
}

\begin{abstract}
The longterm performance of multi-generations or life span was assessed using genetically modified (GM) insect-resistant Bt11 corn. Diet containing 68\% of GM Bt11 or non-Bt isoline with sufficient nutrient composition was fed to male and female ICR mice through 5 generations. The results of growth, mating, gestation, milking periods, reproduction and life span were not different between the GM Bt11 and non-Bt fed groups. The percentage of embryonic death, litter size, newborn sex ratio and body weight (21-60 days after birth) were not different between these groups. The life span of the third-generation mice did not differ over 1,072 days of observation. In addition, there was a tendency for a weight decrease among each group as the generations progressed, but there was no significant difference in performance among each group in each generation of mice.
\end{abstract}

Key Words: Genetically modified, corn, biosafety, longterm performance.

\section{INTRODUCTION}

Genetically modified (GM) plant products are being widely used now in the farm industry, and thus by consumers. One of the keys to acceptance of use of GM is "substantial equivalence" of the products [1-11]. This means that there is no change of the products except for GM gene and its subsequent effects, while most of consumers use GM products daily and through subsequent generations without making any sure reliable information about their bio-safety. The consumers still have vague fairs of unexpected effects of using GM products, and want to get conformation about the safety of GM products from scientific journals. However, most of the animal performance were done in short term and case by case manner. There have been number of papers on animal experiments read in academic meetings or conferences, also many reports including reviews on bio-safety assessment of GM products have been published in scientific journals $[1-8,12]$. However, there still have been a few longterm biosafety assessments conducted using multi-generations or life span of animals. The present study, therefore, was a report on longterm biosafety assessment through five generations or whole life span of mice.

\section{LONGTERM BIOSAFETY ASSESSMENT}

Diet

A suitable diet for longterm performance assessment was based on AIN-93 composed of $67.85 \%$ of maize [13]. The

*Address correspondence to this author at the Team for Safety Research, National Institute of Animal Health, Kannondai, Tsukuba, 305-0856, Japan; E-mail: yasunk@affrc.go.jp basic diet used was a commercially available rodent diet for breeding "CE-2, CLEA Jpn" containing soybean, wheat, grain sorghum, fish meal and corn. The GM Bt11 (Bt) corn (N58-D1 Lot \#2608611) or non-Bt isoline (NX5768 Lot \#2608612) purchased from Novartis Seed, Inc. (Greensboro, NC) was substituted for corn ingredients. The applied diets were composed of $12.8 \%$ of crude protein, $5.1 \%$ crude lipid, $67.6 \%$ nitrogen-free extract, $0.9 \%$ calcium and $0.75 \%$ phosphate (Table $\mathbf{1}$ ).

Table 1. Components of the Diet Fed to Mice. Corn Starch Used was Derived from non-Bt Corn

\begin{tabular}{|c|c|}
\hline Materials & Amount (\%) \\
\hline \hline Corn (Bt11 or non-Bt) & 67.85 \\
\hline Milk casein & 8.4 \\
\hline DL-methionine & 0.05 \\
\hline Corn oil (Bt11 or non-Bt) & 3.0 \\
\hline Corn starch* & 10.0 \\
\hline Cellulose powder & 5.0 \\
\hline AIN-76 mixed mineral & 1.0 \\
\hline AIN-76A vitamins & 0.2 \\
\hline Choline bitartrate & 1.0 \\
\hline Calcium carbonate & 3.5 \\
\hline
\end{tabular}

\section{Mice and Sampling}

To observe the clinical performance of the mice, a diet containing GM Bt or non-Bt were fed up to 5 generations [9-11]. Body weight, temp, feed intake, feces check, and 
clinical performance were observed during the experiments. The mice were divided into GM Bt fed female or male and non-Bt fed female or male groups. Four mice were placed in one cage, and the room temp was maintained at $25 \mathrm{C}$, with a $12 \mathrm{hr}$ light/dark cycle. The bedding was changed twice a week. Water was available ad libitum. The experiments were conducted under the Guideline for the Use of Laboratory Animals, National Institute of Animal Health.

Generation 0 (F0) consisted of 4 week-old ICR mice of 4 groups (GM Bt and non Bt; 31 females and 16 males each). They were fed either the GM Bt11 or non-Bt. Between 60 and 70 days old, they were cross-bred, and the rate of vaginal plug formation, delivery rate and period, number of fetuses, rate of male and female fetuses born, and weaning period were checked. After the end of the weaning, the F0 mice were sacrificed for autopsy (Table 2).

The derived fetuses were labeled as F1, and similar subchronic performance from breeding to breeding of next generation was done in F1 through F3 (Table 2). To examine the effects of GM in pregnant mice and their fetuses, the F4 generation derived from F3 (16 pregnant mice in the GM Bt group and 22 pregnant mice in the non-Bt group) was crossed and the pregnant mice were sacrificed after 18 days of plug formation ( 1 day before delivery). The number of fetuses, and presence of abnormalities in the fetuses were checked, and the sizes and weights of the placenta and ovaries were measured to compare between the GM Bt group and non-Bt (Table 3). In addition, performance during life span in the F3 was assessed, and a pathological examination conducted at the end of the span (Table 4, Fig.4). The significance was assessed using the Student's $t$-test.

\section{Feed Intake and Body Weight}

In the F0 and F1 generations, preference for the GM Bt feed did not differ with that of non-Bt, as suggested by feed intake. There also were no significant differences in gain of body weight (Figs. 1, 2). Feed intake varied individually, but

Table 2. Reproduction in F0 and F1

\begin{tabular}{|c|c|c|c|c|c|c|c|c|c|c|}
\hline Group & & & \multicolumn{3}{|c|}{ Selected } & \multicolumn{2}{c|}{ Weaned } \\
\hline \hline F0 & Crossed & Plug & Birth & Total & Female & Male & Total & Female & Male \\
\hline non-Bt & 31 & 29 & 27 & 216 & 99 & 117 & 207 & 98 & 109 \\
\hline GM Bt & 31 & 23 & 27 & 216 & 108 & 108 & 212 & 106 & 106 \\
\hline & & & & & \multicolumn{2}{|c|}{ Selected } & Weaned \\
\hline F1 & Crossed & Plug & Birth & Total & Female & Male & \multicolumn{2}{|c|}{ Total } & Female & Male \\
\hline non-Bt & 46 & 10 & 5 & 38 & 21 & 17 & 36 & 21 \\
\hline GM Bt & 49 & 21 & 17 & 107 & 52 & 55 & 106 & 51 \\
\hline
\end{tabular}

Table 3. Weight of Fetus, Ovary, Placenta, Uterus and Number of Fetuses in 18 Days of Pregnancy (F4)

\begin{tabular}{|c|c|c|}
\hline F4 mice & Gm Bt (n=16) & non-Bt (n=22) \\
\hline \hline Body weight (g & $56.53 \mp 6.33$ & $54.24 \mp 4.16$ \\
\hline Uterus (g) & $19.60 \mp 4.63$ & $19.66 \mp 3.16$ \\
\hline Fetus (g) & $1.22 \mp 0.18$ & $72.99 \mp 15.54$ \\
\hline Placenta (mg) & $75.70 \mp 15.07$ & $11.50 \mp 3.36$ \\
\hline Ovary (mg) & $10.87 \mp 4.64$ & $12.45 \mp 2.24$ \\
\hline Live fetus (n) & $12.75 \mp 3.09$ & $0.80 \mp 1.20$ \\
\hline Died (n) & $0.31 \mp 0.60$ & $0.70 \mp 1.03$ \\
\hline Absorbed (n) & $0.75 \mp 0.93$ & \\
\hline
\end{tabular}

Table 4. Lifespan in Days of the F3 Generation Mice. (f): Female, (m): Male

\begin{tabular}{|c|c|c|c|c|c|c|c|}
\hline & Number & Mean & S.D. & Longest & Shortest & Median & Variance \\
\hline \hline non GM (f) & 44 & 694 & 154 & 981 & 345 & 687 & 23688 \\
\hline GM (f) & 45 & 677 & 188 & 1072 & 269 & 653 & 35181 \\
\hline non GM (m) & 45 & 675 & 158 & 1014 & 252 & 673 & 23688 \\
\hline GM (m) & 45 & 656 & 148 & 1011 & 351 & 681 & 35181 \\
\hline
\end{tabular}




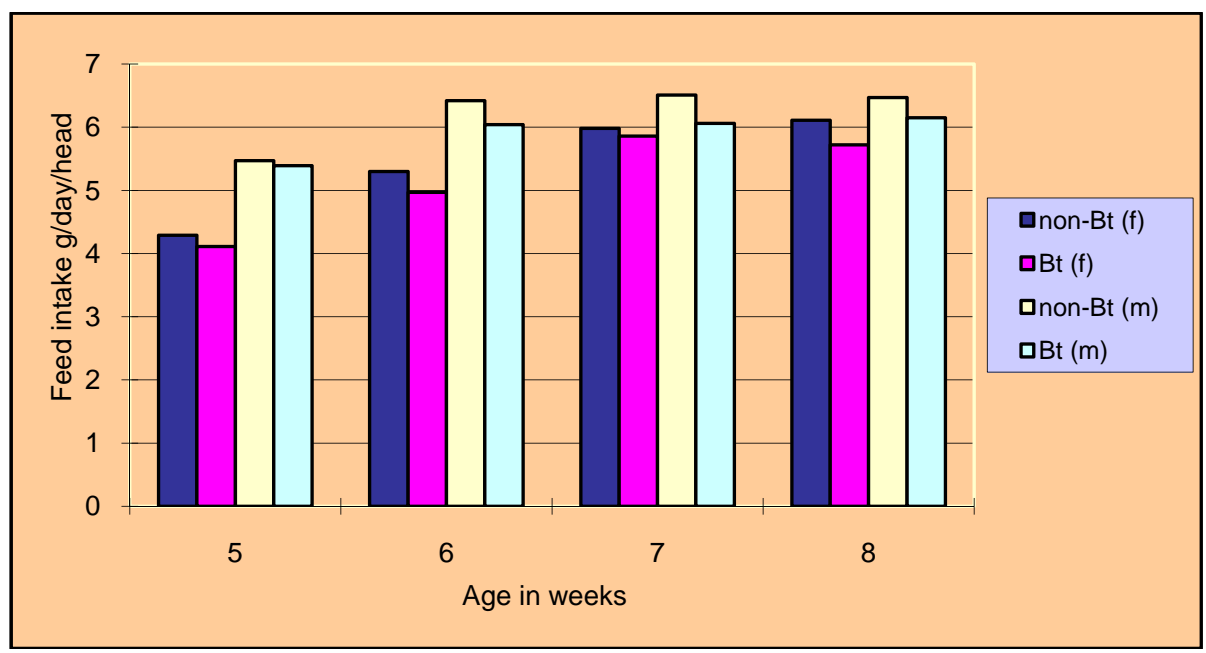

Fig. (1). Feed intake in the F1 mice.

the difference was not significant between the GM Bt and non-Bt groups. In addition, the mean body weight of the F3 mice in the GM Bt group from 1 to 9 weeks was higher than in the non-Bt with significance $(\mathrm{p}<0.05)$, while feed intake was not significantly different in either of the two groups.

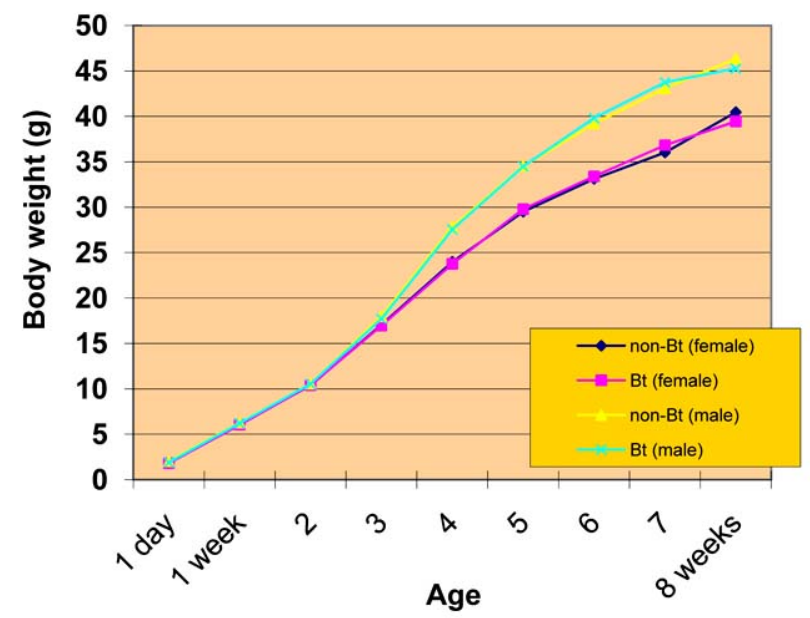

Fig. (2). Body weight in the F1 mice.
Fig. (3) compares the body weight of the 8 week-old mice in each generation. There was a tendency for a weight decrease as the generations progressed, but in each generation, also there were no significant difference among each group of mice. The decrease would be due to feeding a higher contents of corn, $68 \%$, to multi-generations rather than the feeding of GM materials. In addition, the body weight of the mice significantly increased in the GM Bt group in F3; however no conclusion was made from this because similar results were not oBserved in F1 and F2.

\section{Breeding Performance}

The results of pregnancy and birthing such as the number of delivered fetuses or rate of males and females did not differ between the GM Bt and non-Bt groups (Table 2).

In the F0, there were 27/31 delivery mice in both groups, and the delivered fetuses, labeled as F1, consisted of 176 females and 202 males in the GM Bt group, and 172 females and 175 males in the non-Bt, without significant difference in mean number of fetuses per mother and rates of males and females between the two groups. Of them, total of 212 in the GM Bt, and 207 in the non-Bt were weaned (Table 2). In the $\mathrm{F} 1$, the rate of plug formation and birthrate varied, with 17 delivery mice in the GM Bt group and 5 in the non-Bt. The

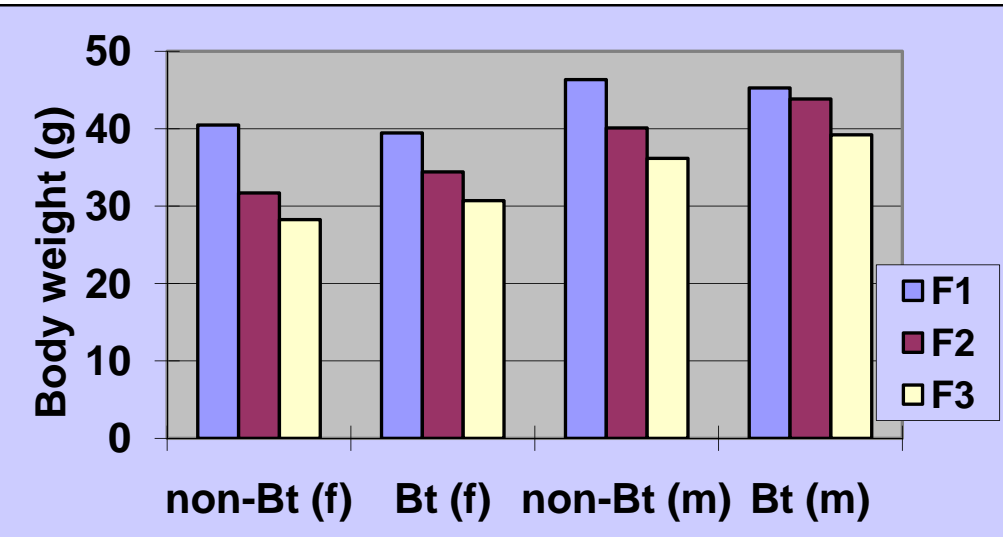

Fig. (3). Body weight of 8 week-old mice. 


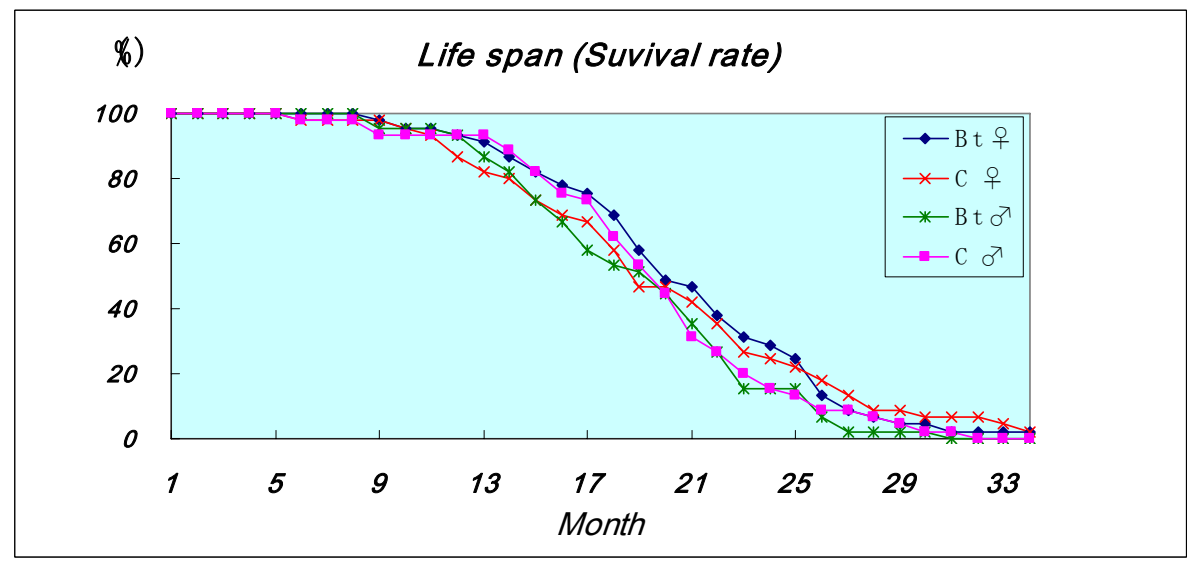

Fig. (4). Life span in months of the F3 mice.

fetuses, labeled as F2, consisted of 51 females and 55 males in the GM Bt group and 21 females and 25 males in the non$\mathrm{Bt}$, without significant difference in mean number and rate of male and female of fetuses between the two groups. In the F3, there were 52 mice which delivered in the GM Bt and 21 in the non-Bt, while of the delivered fetuses, 199 were female and 231 male in the GM Bt, and 93 were female and 81 male in the non-Bt, without significant difference in mean number and rate of female and male fetuses between both groups.

The breeding performance in the F4 generation, as suggested by rates of pregnancy and plug formation between the GM Bt and non-Bt groups, was not significantly different. Total vaginal weight, mean weight of fetuses, mean placental weight, mean ovarian weight, numbers of live fetuses, and dead/absorbed fetuses per pregnant mice were not significantly different between the 18 day pregnant mice of the GM Bt and non-Bt groups (Table 3 ).

\section{Lifespan Assessment}

With regard to the lifespan performance of the F3, the longest was survival time was 1,072 days (37 months) (Table 4). There was no significant difference by statistical analysis with Student's $t$ test. The number of weeks in the GM Bt and non-Bt groups (males and females) survived are also shown in Fig. (4). Cause of death include senility, tumor, malnutrition, internal bleeding, anemia, uremia or ileus. Tumors were detected in 19/45 females and 13/45 males in the GM Bt group, and 15/44 females and 15/45 males in the non-Bt with no significant difference. Histopathological diagnoses of these tumors included lung adenocarcinoma, hepatocyte tumor, malignant lymphoma, histiocytic sarcoma, and interstitial cell tumor. No significant difference was shown between the occurrence of the causes of death, including tumors, and each group. These results showed that the feeding of GM Bt11 did not affect life span of the F3 and breeding performance of the F4 mice.

\section{CONCLUSIONS}

The present results of longterm biosafety assessment showed no significant difference between the GM Bt and non-Bt fed mice in whole life span, and breeding, birthing and growth of mice through multi-generation. Pathological examination after the death of these mice supported no difference between the GM Bt and non-Bt groups. These results were one of reinforcement on biosafety of GM products for consumers who had vague fair for unexpected effect during the use of GM products and want to have certification. In addition, a weight decrease was detected in each group of mice as the generations progressed, which would be due to feeding a higher contents of corn, $68 \%$, to multi-generations.

Certification of the biosafety of GM products needs to appear in scientific journals. Number of animal performances have been done in short term and case by case manner as depending on its cost performance to maintain animals and institutional facilities combined with guidelines of safety assessments [1-11, 13]. Such papers have been read in academic meetings or conferences. Though the sections of introduction, materials and methods, results and discussion are nearly the same except for name of used GM products, such information has become to publish in many scientific journals [1-6, 7, 8]. However longterm assessments through the animal life or multi-generations still have been a small [12].

Ubiquitous plant and enterobacterial gene fragments were ingested then transferred into the bodies through GI contents [14-17], then to the livers of suckling mice through their mother's milk [18], while the GM cry1Ab gene fragment was not detected due to a few number of copy using PCR. Combined with the present results we did not find out any deleterious effects from the chronic ingestion of the GM Bt11 corn. No evidence has been suggested that plant-derived genes are expressed in the mammalian genes. Therefore, routine use of GM Bt11 corn would not be a matter of concern.

\section{REFERENCES}

[1] Alexander TW, Reuter T, Aulrich K, et al. A review of the detection and fate of novel plant molecules derived from biotechnology in livestock production. Anim Feed Sci Technol 2007; 133: 31-62. Ammann K. Bt toxins are not detrimental to human and animal health. Food Feed 2009; 30: 1-74.

[3] Aumaitre A. Safety assessment and feeding value for pigs, poultry and ruminant animals of pest protected (Bt) plants and herbicide tolerant (glyphosate, glufosinate) plants: interpretation of experimental results observed worldwide on GM plants. Ital J Anim Sci 2004; 3(2): 107-21. 
[4] Aumaitre LA. New feeds from genetically modified plants: Substantial equivalence, nutritional equivalence and safety for animals and animal products. Prod Anim 2002; 15(2): 97-108.

[5] Beever DE, Kemp CF. Safety issues associated with the DNA in animal feed derived from genetically modified crops. A review of scientific and regulatory procedures. Nutr Abstr Rev Ser B Livest Feed Feed 2000; 70: 175-82.

[6] Beever DE, Phipps RH. The fate of plant DNA and novel proteins in feeds for farm livestock: a United Kingdom perspective. J Anim Sci 2001; 79: E290-95.

[7] Einspanier R, Klotz A, Kraft J, et al. The fate of forage DNA in farm animals: a collaborative case-study investigating cattle and chicken fed recombinant plant material. Eur Food Res Technol 2001; 212: 129-34.

[8] Flachowsky G, Aulrich K, Böhme H, Halle I. Studies on feeds from genetically modified plants (GMP)-contributions to nutritional and safety assessment. Anim Feed Sci Technol 2007; 133: 230 .

[9] Organisation for Economic Cooperation and Development. Repeated dose 90-day oral toxicity study in rodent. Guideline for Testing of Chemicals. Repeated dose 90-day oral toxicity study in rodents Test Guideline 408. in OECD Guidelines for the Testing of Chemicals. Paris: OECD 1998; p. 10. Available from http://lysander. sourceoecd.org/vl=2531000/cl=18/nw=1/rpsv/cgibin/fulltextew.pl? prpsv=/ij/oecdjournals/1607310x/v1n4/s9/p1.idx or http://www. botanischergarten.ch/OECD/OECD-Repeated-90day-on-Rodents408-998.pdf

[10] Organisation for Economic Cooperation and Development. Considerations for the Safety Assessment of Animal Feedstuffs Derived from Genetically Modified Plants. (eds. Environment), Paris: OECD Environmental Health and Safety Publications 2003; vol. 9: p. 46. ENV/JM/MONO(2003)10 Available from http:// www.olis.oecd.org/olis/2003doc.nsf/43bb6130e5e86e5fc12569fa00
5d004c/4502bee1ca16c943c1256d520028e259/\$FILE/JT00147696. pdf or http://www.oecd.org/biotrack/or http://www.botanischergarten. ch/OECD/OECD-Safety-2003.pdf

[11] Organisation for Economic Cooperation and Development. Draft Guidance Document On Mammalian Reproductive Toxicity Testing and Assessment (eds Environment). Paris: OECD Environmental Health and Safety Publications 2007; vol. 9: p. 73. available from http://www.oecd.org/dataoecd/5/61/39813058.pdf or http://www.botanischergarten.ch/OECD/OECD-DraftGuidance-432007.pdf

[12] Trabalza-Marinucci M, Brandi G, Rondini C, et al. A three- year longitudinal study on the effects of a diet containing genetically modified Bt176 maize on the health status and performance of sheep. Livest Sci 2008; 113(2-3): 178-90.

[13] Reeves PG, Nielsen FH, George C, Fafey GC, Jr. AIN-93 purified diets for laboratory rodents: final report of the American Institution Ad Hoc writing committee on the reformation of the AIN-76A rodent diet. J Nutr 1993; 123: 1939-51.

[14] Chowdhury EH, Mikami O, Murata H, et al. Fate of maize intrinsic and recombinant genes in calves fed genetically modified maize Bt11. J Food Prot 2004; 67: 365-70.

[15] Doerfler W, Schubbert R. Uptake of foreign DNA from environment: the gastrointestinal tract and the placenta as portals of entry. Wien Klin Wochenschr 1998; 110(2): 40-4.

[16] Flachowsky G, Chesson A, Aulrch K. Animal nutrition with feeds from genetically modified plants. Arch Anim Nutr 2005; 59: 1-40.

[17] Munkvold G.P, Desjardins AE. Fumonisins in maize. Can we reduce their occurrence? Plant Dis 1997; 81: 556-65.

[18] Nakasuji S, Koyama S, Takeuchi S, Mikami O, Tanimura N, Nakajima Y. The transfer of ingested plant and enterobacterial fragments into mice bodies and their shift to the livers of suckling mice through mother's milk. Int J Food Eng 2008; 4(8): 0-11.

(C) Haryu et al.; Licensee Bentham Open.

This is an open access article licensed under the terms of the Creative Commons Attribution Non-Commercial License (http://creativecommons.org/licenses/by$\mathrm{nc} / 3.0 /$ ) which permits unrestricted, non-commercial use, distribution and reproduction in any medium, provided the work is properly cited. 